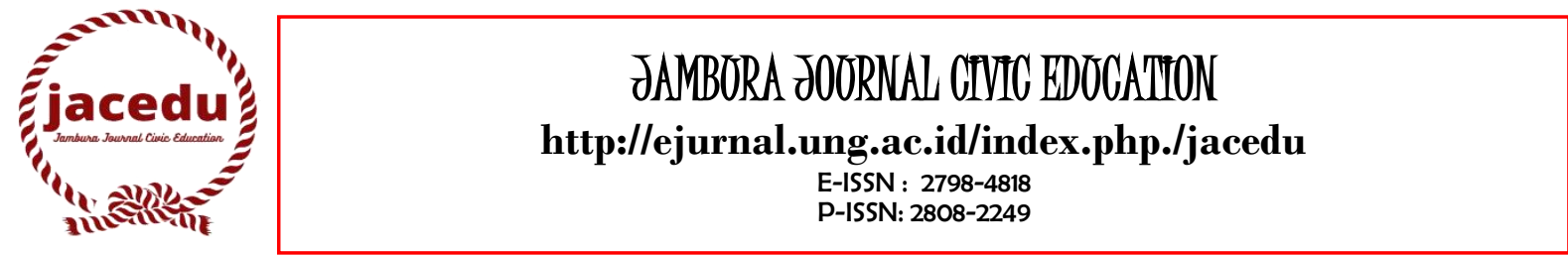

\title{
PENGELOLAAN BUMDES DALAM MENINGKATKAN KESEJATERAAN MASYARAKAT DESA HUYULA, KECAMATAN RANDANGAN, KABUPATEN POHUWATO, PROVINSI GORONTALO
}

\author{
Sastro M Wantu1, Udin Hamim², Zulfikar Adjie ${ }^{3}$, Ramli Mahmud4 \\ Fakultas Ilmu Sosial, Universitas Negeri Gorontalo \\ (sastrowantu@gmail.com) \\ (udinhamim@gmail.com) \\ (zulfikaradjie@gmail.com) \\ (ramlimahmud33@gmail.com)
}

\begin{tabular}{l}
\hline \multicolumn{1}{c}{ Info Artikel } \\
\hline Sejarah Artikel: \\
Diterima (Desember) (2021) \\
Disetujui (Desember ) (2021) \\
Dipublikasikan (Desember ) \\
(2021)
\end{tabular}

\section{Keywords:}

Bumdes, Kesejahteraan masyarakat

\section{Abstrak}

Penelitian ini membahas tentang pegelolaan bumdes dalam meningkatkan kesejahteraan masyarakat desa Huyula, Kecamatan, Randangan, Kabupaten. Pohuwato. Provinsi Gorontalo. Tujuan penelitian ini untuk mengetahui bagaimana pengelolaan BUMDes dalam meningkatkan kesejateraan masyarakat serta apa saja faktor penyebab rendahnya pengelolaan BUMDes dalam meningkatkan kesejateraan masyarakat. Penelitian ini menggunakan metode kualitatif, metode penelitian kualitatif adalah prosedur penelitian yang menghasilkan data deskritif dalam bentuk kata tertulis atau lisan dari orang-orang dan perilaku yang diamati. Prosedur pengumpulan data yaitu dengan melakukan observasi, wawancara dan dokumentasi. Hasil penelitian ini menunjukan bagaimana pengelolaan BUMDes dalam meningkatkan kesejateraan masyarakat. Dalam pengelolaan BUMDes di Desa Huyula ini baik dari pemerintah desa, pengelola BUMDes dan masyarakat desa masih kurang bekerja sama dengan baik, hal tersebut terlihat dari belum adanya kesesuaian pengelolaan BUMDes sehingga pembentukan program BUMDes tidak berjalan dengan baik, yang berimbas pada tujuan BUMDes dalam mensejaterakan masyarakat desa belum optimal. Adapun faktor penyebab rendahnya pengelolaan BUMDes dalam meningkatkan kesejateraan masyarakat, yaitu terletak pada sumber daya manusia, usaha serta kerjasama yang masih kurang antara pemerintah desa, pengelola BUMDes serta masyarakat desa, sehingganya pembentukan program BUMDes belum berjalan sesuai dengan yang di harapkan dalam mensejaterahkan masyarakat desa.

\footnotetext{
${ }^{1}$ Dosen PPKN UNG

2 Dosen PPKN UNG

${ }^{3}$ Dosen PPKN UNG

${ }^{4}$ Dosen PPKN UNG
} 


\section{PENDAHULUAN}

Salah satu strategi pemerintah memudahkan desa dalam meningkatkan pendapatan asli desa adalah dikeluarkannya Peraturan Menteri Desa, Daerah Tertinggal dan Transmigrasi Nomor 4 Tahun 2015 tentang Pendirian, Pengurusan, Pengelolaan, dan Pembubaran Badan Usah milik Desa yang menyebutkan bahwa pemerintah desa dapat mendirikan Badan Usaha Milik Desa (BUMDes). BUMDes adalah badan usaha yang berasal dari kekayaan Desa yang dipisahkan guna mengelola aset, jasa pelayanan, dan usaha lainnya untuk sebesar-besarnya kesejahteraan masyarakat Desa. Pendirian BUMDes dilandasi oleh UU No. 32 tahun 2004 jo. UU No. 23 tahun 2014 tentang Pemerintahan Daerah, UU No. 6 tahun 2014 tentang desa serta PP No. 72 tahun 2005 tentang Desa. Dalam UU No. 32 tahun 2004 jucto UU No. 23 tahun 2014 tentang Pemerintahan Daerah pada pasal 213 ayat (1) disebutkan bahwa, "Desa dapat mendirikan badan usaha milik desa sesuai dengan kebutuhan dan potensi desa." Dalam 1 angka 4 Peraturan Mentri Dalam Negeri No.39 tahun 2010 tentang Badan Usaha Milik Desa, BUMDes diartikan sebagaimana yang berbunyi: “Badan Usaha Milik Desa, yang selanjutnya disebut BUMDes, adalah usaha desa yang dibentuk atau didirikan oleh pemerintah desa yang kepemilikan modal dan pengelolaannya dilakukan oleh pemerinta desa dan masyarakat." Pendirian BUMDes juga didasari oleh UU No. 6 tahun 2014 tentang Desa dalam Pasal 87 ayat (1) yang berbunyi, "Desa dapat mendirikan Badan Usaha Milik Desa yang disebut BUMDes," dan ayat (2) yang berbunyi, “BUMDes dikelola dengan semangat kekeluargaan dan kegotoroyongan," dan ayat (3) yang berbunyi “BUMDes dapat menjalankan usaha dibidang ekonomi dan atau pelayanan umum sesuai dengan ketentuan peraturan perundang-undangan.

Pada permasalahan yang terjadi di Desa Huyula Kecamatan Randangan Kabupaten Pohuwato Provinsi Gorontalo ini saya sebagai peneliti lebih berfokus pada pengelolaan BUMDes. Seperti yang diketahui bahwa dana yang digunakan untuk pengelolaan pembentukan BUMDes di Desa Huyula yaitu sekitar Rp. 60.000.000 , dana tersebut nantinya akan digunakan untuk mendanai setiap program-program yang akan dijalankan oleh BUMDes. Namun, BUMDes belum membentuk badan usaha sendiri sebagai perputaran dana untuk menghasilkan pendapatan sendiri, seperti yang 
dituturkan oleh ketua BUMdes desa Huyulu mereka telah mengusulkan beberapa bidang usaha tetapi terkendala oleh beberapa hal diantaranya usulan pertama pada bidang pertenakan pengelola BUMDes mengusulkan program pengegemukan sapi akan tetapi terkendala oleh sulitnya ketersediaan pakan sapi sehingga menyebabkan pengelola mungusulakan usulan ke dua mengenai pangkalan gas elpg, pada program pangkalan gas elpg ini terkendala oleh tidak mendapatkan dukungan atau respon dari pemerintah karena program yang diusulkan sudah banyak dijalankan oleh desa-desa lain sehingga program tersebut tidak mendapatkan ijin untuk dijalankan, namun menurut pendapat ketua pengelola BUMDes bahwa penggadaan pangkala elpg tersebut dapat mempercepat perputaran dana karena penyediaan pangkalan elpg masih minim dan masih banyak dibutuhkan oleh masyrakat setempat sehingga pengelola mempunyai inisiatif untuk mengusulkan program tersebut, namun jika bergerak dibidang pertanian dalam penyediaan pupuk dan bibit itu sangat rumit hal ini dikarenakan ketika unit usaha mau memperoleh bibit atau pupuk tersebut maka harus mengupulkan kelompok-kelompok masyarakat sebagai syarat untuk dikeluarkan bahan-bahan seperti bibit dan pupuk atau sejenisnya namun masyarakat disana sudah banyak yang terikat sama tengkulak sehingga menurut pengelolaan BUMDes hal ini akan memperumit pembentukan kelompok-kelompok masyarakat yang berimbas pada tidak terpenuhinya sayarat untuk menjalankan program bidang pertanian tersebut.

Nah dari penuturan pengelolaan BUMDes tersebut dapat disimpulkan bahwa yang menjadi kendala dari BUMDes desa huyula adalah belum terjalinnya komunikasi dan kerjasama yang baik antara pengelola, pemerintah dan masyrakat, sehingga menjadi hambatan dalam pembentukan Unit Usaha Milik Desa (BUMDes), hal ini tentu akan berpengaruh pada tingkata kesejateraan masyrakat jika kita mengacu pada tujuan berdiranya BUMDes yaitu untuk meningkatkan kesejateraan masyarakat dari desa. Dari penjelasan diatas penulis dapat mengangkat judul dari permasalah yang terjadi yaitu Pengelolaan Bumdes Dalam Meningkatkan Kesejateraan Masyarakat Desa Huyula Kecamatan Randangan Kabupaten Pohuwato Provinsi Gorontalo. 


\section{METODELOGI PENELITIAN}

Pendekatan penelitian yang dianggap sesuai untuk digunakan adalah pendekatan kualitatif. Karena, Peneltian kualitatif sering disebut metode penelitian naturalistic karena penelitiannya dilakukan pada kondisi yang alamiah natural setting 21 . Dalam penelitian kualitatif diakukan pada obyek alamiah. Artinya, Obyek yang alamiah adalah obyek yang berkembang apa adanya tidak dimanipulasi oleh peneliti dan kehadirian peneliti dan tidak mempengruhi dinamika pada obyek tersebut. Bogdan etal, mendefinisikan metode penelitian kualitatif adalah prosedur penelitian yang menghasilkan data deskritif dalam bentuk kata tertulis atau lisan dari orang-orang dan perilaku yang diamati. Pendekatan ini diarahkan pada latar dan individu secara holistic (utuh).

\section{HASIL PENELITIAN DAN PEMBAHASAN}

\section{Pengelolaan BUMDes Dalam Meningkatlan Kesejateraan Masyarakat}

Pengelolaan BUMDes adalah suatu upaya yang dilakukan oleh pemerintah desa dan pengelola BUMDes yang bekerja sama dengan masyarakat demi terwujudnya tujuan dari berdirinya BUMDes. Seperti yang diketahui jika pemerintah dan pengelola BUMDes tidak bekerja sama dengan baik serta tidak melibatkan masyarakat maka BUMDes tidak akan terlaksana dan tidak berjalan dengan baik akibat dari kurangnya kerja sama yang baik antara pemerintah desa, pengelola BUMDes serta masyarakat. Adapun yang menjalankan pengelolaan BUMDes disuatu desa diantara lain yaitu: pemerintah desa, pengelola BUMDes serta masyarakat desa

Berdasarkan hasil penelitian, Pengelolaan BUMDes didesa Huyula masih kurang berjalan dengan baik hal tersebut terlihat dari belum berjalannya pembentukan program BUMDes yang dikarenakan perancangan program BUMDes yang belum terealisasi dengan baik sehingganya perlulah ada kesadaran serta kerjasama yang baik antara pemerintah desa, pengelola BUMDes dan Masyarakat desa demi mencapai tujuan dari BUMDes dalam memandirikan dan mensejatrahkan masyarakat desa.

2. Faktor Penyebab Rendahnya Pengelolaan BUMDes Dalam Meningkatkan Kesejateraan Masyarakat 
Dalam pembentukan BUMDes bukanlah hal yang mudah untuk dilaksanakankan mengingat hambatan-hambatan atau kendala-kendala yang mendasari belum dibentuknya Badan Usaha Milik Desa (BUMDes) . Kendala-kendala atau hambatanhambatan tersebut antara lain adalah :

$>$ Sumber Daya Manusia

$>$ Usaha

$>$ Kerjasama

Berdasarkan hasil penelitian, fakor utama dari Rendahnya Pengelolaan BUMDes Dalam Meningkatkan Kesejateraan Masyarakat yaitu terletak pada kurangnya sumber daya manusia, usaha serta kerjasama yang perlu ditingkatkan lagi. Dapat diketahui bahwa Kurangnya sumber daya manusia, usaha serta kerjasama yang meyebabkan pembentukan program BUMDes tidak berjalan sesuai dengan yang harapkan sehingganya dalam mencapai tujuan BUMDes dalam meningkatkan kemandirian serta kesejateraan masyarakat desa akan sulit dilaksanakan sehingganya haruslah ada usaha serta kerjasama yang baik demi meningkatkan pengelolaan BUMDes di Desa Huyula.

\section{KESIMPULAN}

Berdasarkan hasil penelitian yang telah dilakukan oleh penulis mengenai "Pengelolaan Bumdes Dalam Meningkatkan Kesejateraan Masyarakat Desa Huyula Kecamatan Randangan Kabupaten Pohuwato Provinsi Gorontalo". Maka kesimpulan dari hasil penelitian tersebut dapat diuraikan sebagai berikut :

Pengelolaan BUMDes dalam meningkatkan kesejateran masyarakat Desa Huyula ini baik dari pemerintah desa, Pengelola BUMDes maupun masyarakat desa masih kurang bekerja sama dengan baik, hal tersebut terlihat dari belum adanya kesesuaian pengelolaan BUMDes sehingga pembentukan program BUMDes tidak berjalan dengan baik, yang berimbas pada tujuan BUMDes dalam mensejaterakan masyarakat desa belum optimal. Oleh karenanya hal yang perlu dperhatikan terlebih dahulu adalah rasa kesadaran setiap pihak dan kerjasama yang baik dari pemerintah desa, pengelola BUMDes serta masyarakat desa sehingga apa yang menjadi tujuan berjalannya BUMDes 
demi mencapai masyarakat desa yang mandiri dan sejaterah dapat dijalankan di desa Huyula ini.

Faktor-faktor rendahnya pengelolaan BUMDes dalam meningkatkan kesejateraan masyarakat Desa Huyula ini adalah terletak pada sumber daya manusia, usaha serta kerjasama yang masih kurang antara pemerintah desa, pengelola BUMDes serta masyarakat desa. Dapat diketahui bahwa kurangnya sumber daya manusia, usaha serta kerjasama dari semua pihak menyebabkan pembentukan program BUMDes tidak berjalan sesuai dengan yang diinginkan sehingganya dalam mencapai tujuan BUMDes dalam meningkatkan kemandirian serta kesejateraan masyarakat desa akan sulit dilaksanakan sehingganya haruslah ada sumber daya manusia, usaha serta kerjasama yang baik antara pemerintah desa, pengelola BUMDes serta masyarakat desa, sehingga BUMDes dapat berperan aktif dalam hal mensejaterakan masyarakat desa.

\section{DAFTAR PUSTAKA}

Citasari, Dian dkk. 2020. Laode Ida (2002), dalam buku Menejemen Pemerintah. hal, 21, April

Mingharyoso, Mohammad Sudwi.

2018. Pasal 213 ayat (1) UU No. 32 tahun 2004 jo. UU No. 23 tahun 2014 tentang Pemerintahan Daerah, Pasal 1 angka 4 Peraturan Menteri dalam Negeri Nomor 39 tahun 2010 tentang Badan Usaha Milik Desa .

Suhu La, Bakri, Raoda M. Djae, and Abdurahman Sosoda. 2020. Analisis Pengelolaan Badan Usaha Milik Desa (Bumdes) Di Desa Geti Baru Kecamatan Bacan Barat Utara Kabupaten Halmahera Selatan. Jurnal Government Of Archipelago-Jgoa 1.1.

UU NO. 6 "tahun 2014 tentang Desa." (6): 20171106-094054. 2016. Jurnal Dinamika Ekonomi \& Bisnis 13.1

Unggunanto, Edy Yusuf, et al. 2016. Ag Nomor, Undang-Undang Republik Indonesia, tahun 2014 tentang Desa. (6): 20171106-094054. Pengembangan desa mandiri melalui pengelolaan badan usaha milik desa (BUMDes). Jurnal Dinamika Ekonomi \& Bisnis 